\title{
Flatfish monophyly refereed by the relationship of Psettodes in Carangimorphariae
}

\author{
Wei Shi ${ }^{1,2}$, Shixi Chen ${ }^{2,3}$, Xiaoyu Kong ${ }^{2 *}$, Lizhen $\mathrm{Si}^{2}$, Li Gong $^{2}$, Yanchun Zhang ${ }^{2}$ and Hui Yu ${ }^{1 *}$
}

\begin{abstract}
Background: The monophyly of flatfishes has not been supported in many molecular phylogenetic studies. The monophyly of Pleuronectoidei, which comprises all but one family of flatfishes, is broadly supported. However, the Psettodoidei, comprising the single family Psettodidae, is often found to be most closely related to other carangimorphs based on substantial sequencing efforts and diversely analytical methods. In this study, we examined why this particular result is often obtained.

Results: The mitogenomes of five flatfishes were determined. Select mitogenomes of representative carangimorph species were further employed for phylogenetic and molecular clock analyses. Our phylogenetic results do not fully support Psettodes as a sister group to pleuronectoids or other carangimorphs. And results also supported the evidence of long-branch attraction between Psettodes and the adjacent clades. Two chronograms, derived from Bayesian relaxedclock methods, suggest that over a short period in the early Paleocene, a series of important evolutionary events occurred in carangimorphs.

Conclusion: Based on insights provided by the molecular clock, we propose the following evolutionary explanation for the difficulty in determining the phylogenetic position of Psettodes: The initial diversification of Psettodes was very close in time to the initial diversification of carangimorphs, and the primary diversification time of pleuronectoids, the other suborder of flatfishes, occurred later than that of some percomorph taxa. Additionally, the clade of Psettodes is long and naked branch, which supports the uncertainty of its phylogenetic placement. Finally, we confirmed the monophyly of flatfishes, which was accepted by most ichthyologists.
\end{abstract}

Keywords: Mitochondrial genomes, Psettodes, Pleuronectiformes, Molecular clock, Phylogeny

\section{Background}

Flatfishes (order Pleuronectiformes) are divided into two suborders: Psettodoidei, with one family, one genus (Psettodes); and Pleuronectoidei (hereafter pleuronectoids), with 13 families, approximately 128 genera. The eyes of these adult fishes are uniquely located on one side of the body. The absence of transitional species of flatfishes offered an early challenge to theories of evolutionary change through the accumulation of a series of small steps [1].

\footnotetext{
* Correspondence: xykong@scsio.ac.cn; yu71hui@126.com

${ }^{2}$ CAS Key Laboratory of Tropical Marine Bio-resources and Ecology, South

China Sea Institute of Oceanology, Chinese Academy of Sciences, 164 West Xingang Road, Guangzhou 510301, China

'College of Life Science, Foshan University, Foshan 528231, Guangdong, China Full list of author information is available at the end of the article
}

The study of flatfish fossils has been ongoing. Schwarzhans [2] documented the recent and fossil otoliths of the order. Chanet [3] summarized studies regarding the fossils of this order. Friedman [4] named tHeteronectes and re-studied †Amphistium. Friedman [5] placed the Eocene crown-group flatfish †Joleaudichthys in Psettodoidei and two other Eocene crown-group fossils, †Numidopleura and †Eobothus, within Pleuronectoidei. [1].

Two distinct views regarding the origin of flatfishes have been presented [6]. One, proposed by Kyle [7] and Chabanaud [8], considers that all major flatfish lineages were independent offshoots of an evolving "pre-perciform" lineage and treats Psettodes as the descendant of a recent percoid ancestor. However, Chapleau [6] and a number of ichthyologists believe that flatfishes have a

(c) The Author(s). 2018 Open Access This article is distributed under the terms of the Creative Commons Attribution 4.0 International License (http://creativecommons.org/licenses/by/4.0/), which permits unrestricted use, distribution, and 
"lower-percoid" origin. Psettodes has been suggested to be the most "primitive" flatfish [9-11]. The "lower-percoid" origin of flatfishes was recently confirmed by molecular data and is now widely accepted by teleost ichthyologists [12-17].

Moreover, recent studies have confirmed that the most closely related organisms to flatfishes are percomorph taxa, predominantly carangiforms and istiophoriforms, including latids, carangoids, billfishes, moonfish, swordfish, barracudas, archerfishes, snook and threadfins (this group is referred to as the cara group hereafter) [12-15, 18-24]. These taxa and flatfishes were initially collectively referred to as clade $\mathrm{L}$ by Chen et al. [17]. Li et al. [23] named this clade Carangimorpha, which was soon after referred to as Carangimorphariae (hereafter, carangimorphs) by Betancur-R et al. [19, 20], and conferred upon it a new taxonomic rank in a revised classification of bony fishes.

While the monophyly vs. polyphyly of the pleuronectiforms remains disputed, much molecular research on teleostean phylogenies has involved the flatfishes $[12,14$, $15,17,21-23,25]$. Most studies focus on the phylogenetic status of flatfishes among teleosteans (especially percomorphs), but only representatives of pleuronectiforms have been included [13, 22]. Recently, molecular studies with broader taxonomic representation for this prominent group have been performed [12, 18, 19, 26], but the results are highly divergent, especially those presented by two major research groups, Betancur-R. et al. [19, 27] and Campbell et al. [18, 28], who strongly debate flatfish monophyly. Campbell et al. [26] used whole mitochondrial genome sequences to examine the phylogenetic affinities of the flatfishes (Pleuronectiformes) and obtained only weak support for the monophyly of Pleuronectiformes.

In the last ten years, several large-scale fish phylogenetics projects broadly representing the carangimorphs have been performed, which strongly support the monophyly of Pleuronectoidei [18-20, 27]. However, whether the other suborder of flatfishes, Psettodoidei, with close relationship to Pleuronectoidei remains unclear [12, 20, 23, 24, 29]. Betancur-R. et al. [19] conducted a thorough investigation of the phylogeny of flatfishes and their position among percomorphs by combining high genetic coverage (20 loci; ca. $20 \mathrm{kbp}$ ) with dense taxonomic breadth (214 taxa), including all putative flatfishes and a diverse percomorph outgroup. The majority of concatenation topologies provide evidence that flatfish has a single evolutionary origin, although a minority of analyses have inferred a non-monophyletic Pleuronectiformes, with varying placement of Psettodes and pleuronectoid clades among carangimorphs. As mentioned above, these authors support the monophyly of flatfishes. However, Campbell et al. [18] rapidly cast doubt on the monophyly of flatfishes based on six nuclear genes and extensive taxonomic sampling, including flatfishes and potential close relatives (approximately 90 taxa). Their results were most consistent with a non-monophyletic Pleuronectiformes, with Psettodes consistently excluded from other flatfishes and placed among other carangimorphs. Soon thereafter, Campbell et al. [28] and Betancur-R. et al. [27] launched a continuous debate based on more comprehensive data or complete (mitochondrial genome) mitogenome data. This issue has become a hot topic, and there is no consensus. Harrington et al. [30] presented a high-resolution phylogeny using a sequence dataset comprising more than 1000 ultraconserved DNA element loci covering 45 carangimorphs that unequivocally supports flatfish monophyly and a single origin of asymmetry. It remains unclear why so many phylogenetic analyses based on different datasets still have failed to clarify the issue of flatfish monophyly.

Currently, the key problem challenging the monophyly of flatfishes is the phylogenetic placement of Psettodes. What factors are responsible for the inconsistent phylogenetic position of the Psettodes clade? In this study, the mitogenomes of five flatfishes, Psettodes erumei, Samaris cristatus, Achirus lineatus, Trinectes maculatus and Cynoglossus nanhaiensis, were determined, and species data from all 13 flatfish families were compiled. Select mitogenomes of representative carangimorph species were employed for phylogenetic and molecular clock analyses. Based on our evaluation of the evolutionary history of carangimorphs, particularly the evolutionary events during the period of emergence of the Psettodes ancestor, we explain why different molecular phylogenetic studies are so divided on the issue of flatfish monophyly.

\section{Methods}

Sampling, DNA extraction, amplification and sequencing

The Psettodes erumei, Samaris cristatus, Achirus lineatus, Trinectes maculatus and Cynoglossus nanhaiensis specimens used in this study were collected from a seafood market. A summary of the primer sequences and optimized PCR conditions used for amplifying the metagenomes are presented in Additional file 1: Table S1. The obtained PCR products were purified and sequenced in both directions with an ABI 3730 DNA sequencer (Applied Biosystems, USA).

The sequenced fragments were assembled into the mitochondrial genome using CodonCode Aligner v3.5.4 (CodonCode Corporation) and BioEdit v7.2.5 [31]. Annotation and boundary determination for protein-coding genes and ribosomal RNA genes were performed using NCBI-BLAST (http://blast.ncbi.nlm.nih.gov) and tRNAscan-SE [32], with the cut-off values set to 1 when necessary. 
Dense taxonomic sampling can reduce the effects of systematic biases, such as long-branch attraction, on phylogenetic inference [33]. In this study, the complete mitochondrial genome sequences from 50 fishes were employed for phylogenetic analysis. Five new complete mitogenomes were obtained in the present study, and the sequences of the remaining 45 species were retrieved from GenBank. The 47 carangimorphs that were included represented all 13 available families of flatfishes (30 species) as well as all 11 previously studied families (17 species) of percomorphs from Carangimorphariae. Beryx splendens (Beryciformes), Myripristis berndti (Holocentriformes) and Channa maculata (Anabantiformes) were used as outgroup (Table 1).

\section{Phylogenetic analysis}

In all 50 complete mitochondrial genomes, the first $\left(1_{\mathrm{N}}\right)$, second $\left(2_{\mathrm{N}}\right)$ and third codon positions of twelve coding sequences (ND6 excluded due to compositional heterogeneity), 2 rRNAs (R) and 22 tRNAs (T) were concatenated separately and aligned with Clustal X2 [34], and ambiguous sequences were eliminated using Gblock [35]. To determine whether saturation existed in the alignments, the substitution saturation and the substitution vs. Tamura-Nei (TN93) genetic distance in pairwise comparisons were tested with DAMBE [36]. The number of transitional (TS) and transversional (TV) differences in pairwise comparisons increased with increasing evolutionary distance in all aligned datasets. Third codon positions showing saturation were also observed. Thus, the third codon position sequences were defined only as purines and pyrimidines $\left(3_{\mathrm{RY}}\right)$ [26].

Partitioned $1_{\mathrm{N}} 2_{\mathrm{N}}, 1_{\mathrm{N}} 2_{\mathrm{N}} \mathrm{RT}, 1_{\mathrm{N}} 2_{\mathrm{N}} 3_{\mathrm{RY}}$ and $1_{\mathrm{N}} 2_{\mathrm{N}} 3_{\mathrm{RY}} \mathrm{RT}$ sequences were employed to perform Bayesian inference (BI) analyses in MrBayes 3.2 [37] based on a partitioning strategy for complete mitogenome data described by previous phylogenetic studies with complete mitogenomes [16, 26, 38]. The best-fit models of nucleotide substitution for each of the sequences were selected under different partitioning strategies using MrModelTest 2.1 [39]. Bayesian phylogenetic analyses were performed using "Lset" and "Prset", and the program was allowed to converge on the best estimates of the model parameters. Other parameter settings were as follows: Each Markov chain was initiated from a random tree and run for $5.0 \times 10^{6}$ generations, with every 100th generation being sampled from the chain to assure independence of the samples. Four chains (three heated (temperature $=0.5$ ) and one cold) were run simultaneously using the Metropolis-coupled Markov chain Monte Carlo (MCMCMC) method to enhance the mixing capabilities of the Markov chains. To examine whether stationarity had been reached, the fluctuating values of likelihood and all the phylogenetic parameters were monitored graphically, and simulation analysis was performed twice, starting from different random trees, until the average standard deviation of split frequencies fell below 0.01 .

Partitioned $1_{\mathrm{N}} 2_{\mathrm{N}}, 1_{\mathrm{N}} 2_{\mathrm{N}} \mathrm{RT}, 1_{\mathrm{N}} 2_{\mathrm{N}} 3_{\mathrm{RY}}$ and $1_{\mathrm{N}} 2_{\mathrm{N}} 3_{\mathrm{RY}} \mathrm{RT}$ information was also input into RAxML software [40] for maximum likelihood (ML) analysis. A general time-reversible model with sites following a discrete gamma distribution (GTRGAMMA) was used. A rapid bootstrap (BS) analysis was conducted with 200 replications, and the software produced a best-scoring ML tree with BS probabilities.

\section{Molecular clocks}

The mtDNA datasets were partitioned as follows: concatenated codon positions first $\left(1_{\mathrm{N}}\right)$, second $\left(2_{\mathrm{N}}\right), 2$ rRNA (R) and 22 tRNA (T). We employed the $1_{N} 2_{N} R T$ data-coding scheme in the divergence time analysis. BI under various relaxed-clock models, implemented with MultiDivTime [41] and BEAST v1.7.5 [42], was used to perform molecular dating.

Under the MultiDivTime approach, branch lengths were estimated using ESTBRANCHES, with a fixed tree topology in which the flatfishes were constrained to cluster into a single clade. Next, MULTIDIVTIME was employed to estimate the prior and posterior ages of branching events, standard deviations and 95\% credibility intervals. The Markov chain was run for 10,000,000 generations and sampled every 100 generations after an initial burn-in period of 1000,000 cycles. Other parameters were as follows: The priors for the mean and standard deviation of the ingroup root age, $\mathrm{rttm}$ and $\mathrm{rttmsd}$, were set to equivalents of 70 million years and 10 million years (i.e., $\mathrm{rttm}=0.7$, $\mathrm{rtmsd}=0.1$ ), respectively. The prior mean and standard deviation for the Gamma distribution describing the rate at the root node (rtrate and rtratesd) were both set to 0.34 . These values were based on the median of the substitution path lengths between the ingroup root and each terminal and divided by $\mathrm{rttm}$ (as suggested by the author). The prior mean and standard deviation for the Gamma distribution of the parameter controlling rate variation over time (i.e., brownmean and brownsd) were both set to 2.85 .

In the BEAST analyses, the uncorrelated lognormal model was used to describe the relaxed clock, while GTR + I + G was used to describe the substitution model for the four partitions of the dataset. The Yule process was employed to describe speciation. The constrained tree in which all flatfishes were clustered together was used as the input topology. The means and standard deviations of the lognormal distribution for each calibration point were chosen so that $95 \%$ of the probability lay within the minimum and the maximum boundaries, and the means were the arithmetical medians of the 
Table 1 Description of the 50 species included in this study. Classification follows Nelson [1]

\begin{tabular}{|c|c|c|c|c|}
\hline Taxa & Order & Family & Species & Accession NO \\
\hline \multirow[t]{30}{*}{ Flatfishes } & \multirow[t]{30}{*}{ Pleuronectiformes } & Psettodidae & Psettodes erumei & NC_020032 \\
\hline & & \multirow[t]{3}{*}{ Citharidae } & Citharoides macrolepis & / \\
\hline & & & Citharoides macrolepidotus & NC_024948 \\
\hline & & & Lepidoblepharon ophthalmolepis & NC_024952 \\
\hline & & Scophthalmidae & Psetta maxima & NC_013183 \\
\hline & & \multirow[t]{3}{*}{ Paralichthyidae } & Pseudorhombus cinnamoneus & NC_022447 \\
\hline & & & Pseudorhombus dupliciocellaius & NC_029323 \\
\hline & & & Cyclopsetta fimbriata & NC_024950 \\
\hline & & \multirow[t]{3}{*}{ Pleuronectidae } & Platichthys stellatus & NC_010966 \\
\hline & & & Pleuronichthys cornutus & NC_022445 \\
\hline & & & Hippoglossus stenolepis & NC_009710 \\
\hline & & \multirow[t]{3}{*}{ Bothidae } & Crossorhombus azureus & NC_022446 \\
\hline & & & Lophonectes gallus & NC_030367 \\
\hline & & & Bothus myriaster & NC_030365 \\
\hline & & Poecilopsettidae & Poecilopsetta natalensis & / \\
\hline & & \multirow[t]{3}{*}{ Rhombosoleidae } & Pelotretis flavilatus & NC_026284 \\
\hline & & & Colistium nudipinnis & NC_023447 \\
\hline & & & Peltorhamphus novaezeelandiae & NC_023448 \\
\hline & & Achiropsettidae & Neoachiropsetta milfordi & NC_024953 \\
\hline & & \multirow[t]{2}{*}{ Samaridae } & Samaris cristatus & NC_025903 \\
\hline & & & Samaris cuslatus & NC_024263 \\
\hline & & \multirow[t]{2}{*}{ Achiridae } & Achirus lineatus & NC_023768 \\
\hline & & & Trinectes maculatus & NC_023769 \\
\hline & & \multirow[t]{3}{*}{ Soleidae } & Zebrias quagga & NC_023225 \\
\hline & & & Solea ovata & NC_024610 \\
\hline & & & Heteromycteris japonicus & NC_024921 \\
\hline & & \multirow[t]{4}{*}{ Cynoglossidae } & Paraplagusia blochii & NC_023228 \\
\hline & & & Symphurus plagiusa & JQ639061 \\
\hline & & & Symphurus orientalis & NC_027656 \\
\hline & & & Cynoglossus nanhaiensis & MH317761 \\
\hline \multirow[t]{14}{*}{ Cara-group } & Holocentriformes & Holocentridae & Myripristis berndti & AP002940 \\
\hline & \multirow[t]{7}{*}{ Carangiformes } & \multirow[t]{2}{*}{ Coryphaenidae } & Coryphaena equiselis & AB355907 \\
\hline & & & Coryphaena hippurus & AB355908 \\
\hline & & Rachycentridae & Rachycentron canadum & NC_011219 \\
\hline & & Echeneidae & Echeneis naucrates & NC_022508 \\
\hline & & \multirow[t]{2}{*}{ Carangidae } & Carangoides armatus & NC_004405 \\
\hline & & & Seriola dumerili & NC_016870 \\
\hline & & Menidae & Mene maculata & AB355909 \\
\hline & \multirow[t]{6}{*}{ Istiophoriformes } & \multirow[t]{2}{*}{ Sphyraenidae } & Sphyraena barracuda & NC_022484 \\
\hline & & & Sphyraena japonica & NC_022489 \\
\hline & & Xiphiidae & Xiphias gladius & NC_012677 \\
\hline & & \multirow[t]{3}{*}{ Istiophoridae } & Makaira indica & NC_012675 \\
\hline & & & Istiophorus albicans & NC_022478 \\
\hline & & & Istiophorus platypterus & NC_012676 \\
\hline
\end{tabular}


Table 1 Description of the 50 species included in this study. Classification follows Nelson [1] (Continued)

\begin{tabular}{|c|c|c|c|c|}
\hline Taxa & Order & Family & Species & Accession NC \\
\hline & Anabantiformes & Channidae & Channa maculata & JX978724 \\
\hline & Perciformes & Polynemidae & Polydactylus plebeius & NC_026235 \\
\hline & & & Polydactylus sextarius & NC_027088 \\
\hline \multirow[t]{3}{*}{ Outgroup } & Beryciformes & Berycidae & Beryx splendens & AP002939 \\
\hline & Perciformes & Latidae & Lates calcarifer & NC_007439 \\
\hline & & Toxotidae & Toxotes chatareus & NC_013151 \\
\hline
\end{tabular}

intervals. An MCMC test run with $10^{6}$ generations was first performed to optimize the scaling factors of the priori function. For every individual analysis, the final MCMC chain was run twice for 30 million generations, sampled every 1000 generations. The burn-in and convergence of the chains were determined with Tracer 1.3 [42].

Four calibration points were used in MultiDivTime and BEAST analyses, as performed by Near et al. [29]: (1) date of the most recent common ancestor (MRCA) of Carangidae, Rachycentridae and Echeneidae: 55.8 million years ago (Mya) as the minimal age offset and 63.9 Mya as the $95 \%$ soft upper boundary (BEAST: mean $=0.776, \mathrm{SD}=0.8$ and offset $=55.8$; MultiDivTime: $0.55-0.65$ ); (2) date of the MRCA of Rachycentridae and Echeneidae: 30.1 Mya as the minimal age offset and $34.5 \mathrm{Mya}$ as the $95 \%$ soft upper boundary (BEAST: mean $=0.165, \mathrm{SD}=0.8$ and offset = 30.1; MultiDivTime: 0.3-0.35); (3) date of the MRCA of Soleidae and Cynoglossidae: 40.4 Mya as the minimal age offset and 50 Mya as the $95 \%$ soft upper boundary (BEAST: mean $=0.946, \mathrm{SD}=0.8$ and offset $=40.4$; MultiDivTime: 0.4-0.5); and (4) date of the MRCA of Paralichthyidae, Bothidae and Pleuronectidae: 30.0 Mya as the minimal age offset and 34.4 Mya as the 95\% soft upper boundary (BEAST: mean $=0.165, \mathrm{SD}=0.8$ and offset $=30$; MultiDivTime: 0.3-0.35).

\section{Results}

Phylogenetic analysis based on mitochondrial genomes Eight phylogenetic topologies were obtained: $1_{\mathrm{N}} 2_{\mathrm{N}} \mathrm{BI}$, $1_{\mathrm{N}} 2_{\mathrm{N}} \mathrm{RT}-\mathrm{BI}, \quad 1_{\mathrm{N}} 2_{\mathrm{N}} 3_{\mathrm{RY}}$ BI, $\quad 1_{\mathrm{N}} 2_{\mathrm{N}} 3_{\mathrm{RY}}$ RT-BI, $\quad 1_{\mathrm{N}} 2_{\mathrm{N}-}$ ML, $1_{N} 2_{N}$ RT-ML, $1_{N} 2_{N} 3_{R Y-M L}$ (Additional file 2: Figure S1 a-g) and $1_{\mathrm{N}} 2_{\mathrm{N}} 3_{\mathrm{RY}}$ RT-ML (Fig. 1). The eight topologies showed most flatfish families were monophyletic, including Pleuronectidae, Bothidae, Rhombosoleidae, Samaridae, Achiridae, Soleidae, and Cynoglossidae. The Citharidae and Achiriae clades were sisters to the other pleuronectoids as a whole, while three distinct clades were formed in the pleuronectoids: one stable clade included Paralichthyidae, Pleuronectidae and Bothidae, another included Poecilopsettidae, Samaridae, Soleidae and Cynoglossidae, and the third included Rhombosoleidae and Achiropsettidae (Fig. 1). However, not all flatfish families always clustered together; some cara-group taxa were inserted in the pleuronectoid clade and especially the Citharidae clade (Fig. 1 and Additional file 2: Figure S1 a-g). The close relationship between these cara-group taxa and Citharidae was not supported by high PPs or BPs in the topologies, which is consistent with the results of previous studies $[18,19,26]$. Without inclusion of these cara-group taxa, all the topologies supported the monophyly of pleuronectoids (Additional file 2: Figure S1a-g).

Most significantly, the placement of the Psettodes clade differed greatly among the eight topologies. The sister relationships of Psettodes in each topology are listed in Table 2. The clustering of the Psettodes clade with pleuronectoids arose only in the $1_{\mathrm{N}} 2_{\mathrm{N}}$-BI topology (Additional file 2: Figure S1a), while in four other topologies, the Psettodes clade was clustered with different cara-group families or the main clade containing all cara-group families (Additional file 2: Figure S1c-e, g). In the other three topologies, among which one tree was based on the most informative datasets (Fig. 1), the Psettodes clade was the first to diverge from the entire carangimorph clade (Fig. 1; Additional file 2: Figure S1 b, f).

\section{Origin and evolution of Psettodes}

We used our mitogenome dataset to estimate divergence times for major lineages of carangimorphs employing methods implemented in MultiDivTime [41] and BEAST [42]. Overall, the two dating methods yielded similar results, although some divergence time estimates were slightly different between the two methods. In the MultiDivTime analysis, the partitioned Bayesian approach estimated that the dichotomic time between the flatfishes and cara-group taxa was in the early Paleocene, approximately 64.9 Mya (Fig. 2, node a), and suggested that modern Psettodes originated during the same period in the early Paleocene, approximately 63.3 Ma (Fig. 2, node c). The dichotomic time for pleuronectoids was in the middle Paleocene, approximately 61.2 Mya (Fig. 2, node d), followed by subsequent expansion to form the 12 extant families. In the overall evolutionary process, Psettodes was not observed to experience any species expansion, with a single genus being maintained for approximately 60 million years. 


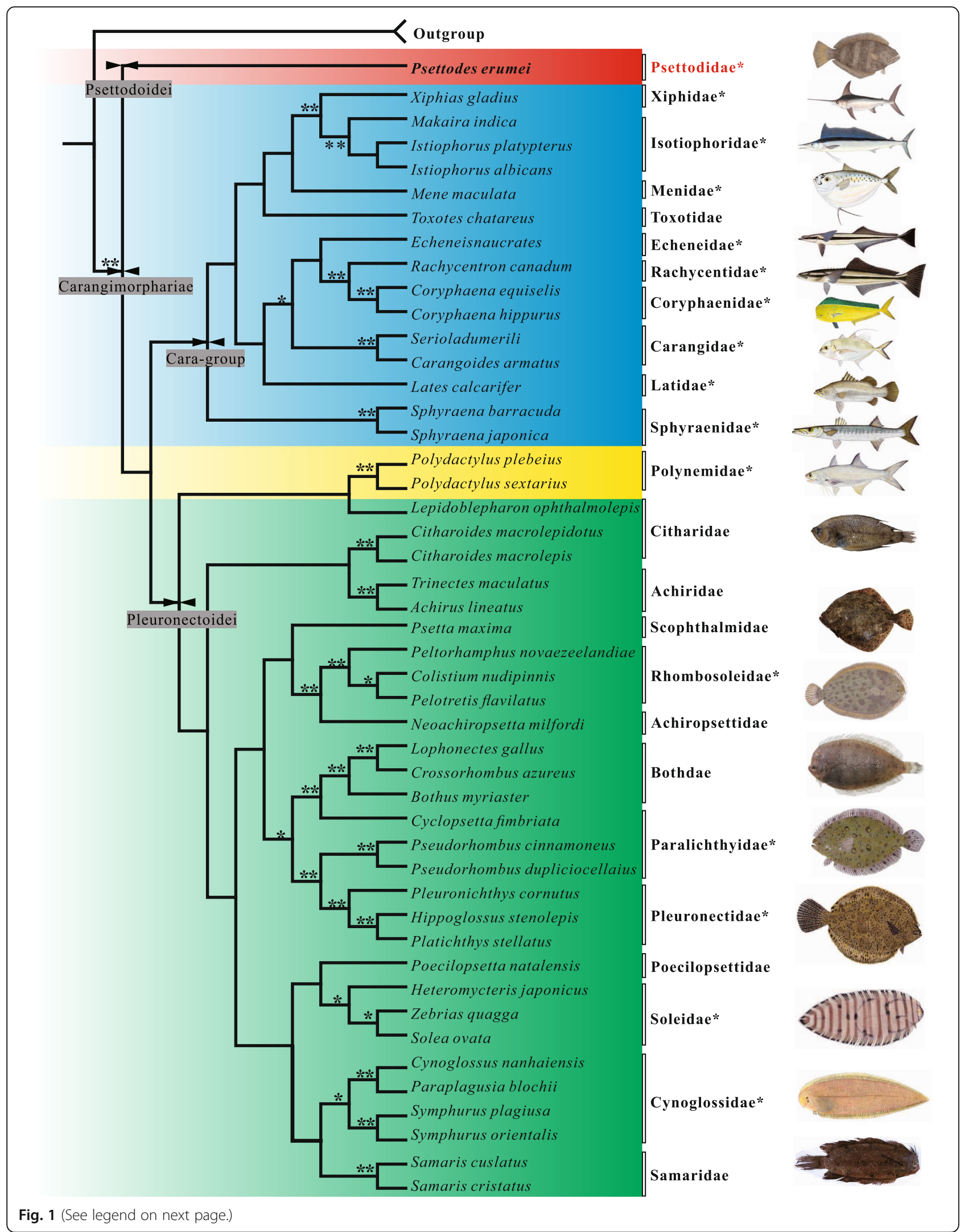


(See figure on previous page.)

Fig. 1 Maximum likelihood (ML) tree generated in RAxML version 8.0.0 under a GTR $+\lceil$ model of nucleotide evolution. The sequences of the first and second codon positions of coding sequences, the third codon position mitochondrial sequences (as purines and pyrimidines), and rRNA and tRNA $\left(1_{N} 2_{N} 3_{R Y} R T\right)$ were used; the Psettodes background is red, while the cara-group taxon background is blue and yellow, and the Pleuronectoidei background is green. ${ }^{*}$ on the branches indicates $>50 \% \mathrm{BPs} .{ }^{* *}$ indicates $100 \% \mathrm{BPs}$. The fish freehand images marked with asterisk were provided by Bernard P.H. YAU, and the other photographs were taken by Kong XY

Accordingly, the initial diversification of the cara group also occurred in the early Paleocene, approximately 63.8 Mya (Fig. 2, node b). After approximately a half Mya, two clades of cara-group taxa underwent further diversification, which indicated that the cara-group taxa experienced speciation expansion in the early Paleocene.

We also mapped all the diversification times at the family level. Most divergences were concentrated within the Paleocene and early Eocene, and for a long time thereafter, there were only a couple of diversification events at the family level (Fig. 2, gray lines). The mapping reveals that during the Paleocene and early Eocene, both flatfishes and the cara-group taxa experienced diversification.

\section{Discussion}

\section{Unstable phylogenetic placement of Psettodes}

To balance the phylogenetic tree and reduce branch attraction error, we supplemented the complete mitogenome sequence data for Achiridae (Achirus lineatus, Trinectes maculatus) and Samaridae (Samaris cristatus, Samaris cuslatus) and ensured that species data were available from all 13 flatfish families. An analytical strategy of balanced taxon sampling was chosen, and only 47 species from Carangimorphariae were intensively reselected, including 17 cara-group fishes and 30 flatfishes, with only $1-4$ species being sampled from the carangimorph families in this phylogenetic analysis (Table 1). Based on the partitioning strategy for complete mitogenome data used by Campbell [26], four representative partitioned datasets $\left(1_{\mathrm{N}} 2_{\mathrm{N}}, 1_{\mathrm{N}} 2_{\mathrm{N}} \mathrm{RT}, 1_{\mathrm{N}} 2_{\mathrm{N}} 3_{\mathrm{RY}}\right.$, and $1_{\mathrm{N}} 2_{\mathrm{N}} 3_{\mathrm{RY}} \mathrm{RT}$ ) were selected and subjected to RAxML (ML) analyses and BI.
The phylogenetic topologies constructed this study are slightly different from those of previous studies. For example, Betancur-R. et al. [19] concluded that flatfishes are a monophyletic group based on the results of a majority of their concatenation topologies. In contrast, Campbell et al. [18] found that Psettodes consistently clustered within the cara-group taxa and confirmed the paraphyly of Pleuronectiformes. In our study, most of the topologies showed that Psettodes did not group with the other flatfishes, but these topologies did not consistently group Psettodes with fixed cara-group fishes. An additional finding of the present study that has not been reported by previous work was that three of our topologies excluded Psettodes not only from other flatfishes but also from cara-group fish, representing the first split from all carangimorphs (Fig. 1 and Table 2). Thus, the topologies do not consistently support Psettodes as the sister to pleuronectoids, the sister to cara-group taxa or the sister to all other carangimorphs.

\section{Reason for the inconsistent phylogenetic placement of Psettodes}

If important evolutionary events occurred in the period of Psettodes divergence, they would have influenced branch attraction in the phylogenetic analysis. Molecular clock analysis can not only provide the origin timing of the Psettodes lineage based on sequence information from modern species but also indicate the evolutionary events that occurred in closely related lineages in the same period. Important evolutionary events can be the cause of branch attraction in phylogenetic analyses. The chronograms derived from the Bayesian relaxed-clock methods provide following insights. Within a short period in the early Paleocene, a series of important

Table 2 Summary of phylogenetic sister relationships of Psettodes in the eight analyses

\begin{tabular}{llll}
\hline Method & Partition & Psettodes sister relationship to & Phylogenetic tree \\
\hline Bayes & $1_{N} 2_{N}$ & Pleuronectiformes $^{a}$ & Additional file 2: Figure S1a \\
& $1_{N} 2_{N} 3_{R Y}$ & Menidae+Latidae+Toxotidae+Istiophoridae+Xiphiidae+Carangidae & Additional file 2: Figure S1b \\
& $1_{N} 2_{N} R T$ & Cara-group+Pleuronectiformes & Additional file 2: Figure S1c \\
& $1_{N} 2_{N} 3_{R Y} R T$ & Cara group & Additional file 2, Figure S1d \\
& $1_{N} 2_{N}$ & Latidae+Toxotidae+Istiophoridae+Xiphiidae & Additional file 2: Figure S1e \\
RAxML & $1_{N} 2_{N} 3_{R Y}$ & Menidae+Toxotidae+Istiophoridae+Xiphiidae & Additional file 2: Figure S1 g \\
& $1_{N} 2_{N} R T$ & Cara-group+Pleuronectiformes & Additional file 2: Figure S1f \\
& $1_{N} 2_{N} 3_{R Y} R T$ & Cara-group+Pleuronectiformes & Figure 1 \\
\hline
\end{tabular}

${ }^{a}$ Polynemidae and Sphyraenidae are excluded. 


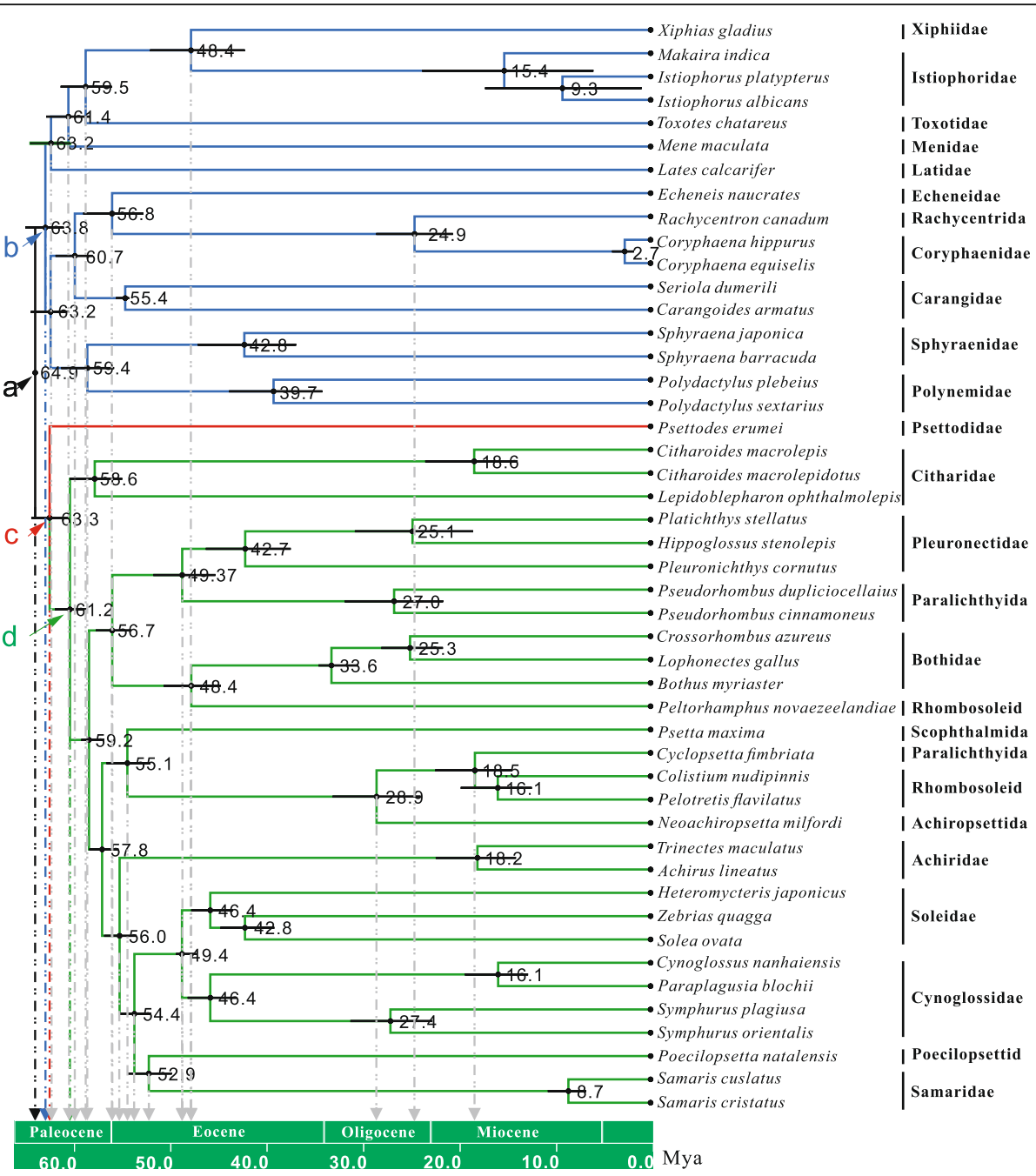

Fig. 2 Divergence times determined using a partitioned Bayesian relaxed molecular clock method. Only partial sequences of the first and second codon positions of coding sequences, rRNA, and tRNA $\left(1_{N} 2_{N} R T\right)$ were used. The numbers beside the nodes indicate the divergence time estimated by MultiDivTime in millions of years (Mya). The horizontal bar at the node indicates the $95 \%$ highest probability density; a: the first dichotomic time of carangimorphs, b: the first dichotomic time of cara-group taxa, c: the first dichotomic time of flatfish taxa and d: the first dichotomic time of pleuronectoid taxa. Gray downward lines indicate the dichotomic time at the level of family

evolutionary events occurred in Carangimorphariae, including the initial divergence between pleuronectiforms and cara-group taxa (Fig. 2, node a); the origin of Psettodes (Fig. 2, node c); and the subsequent speciation expansion of the cara group (Fig. 2, node b). Restoring the evolutionary course, Psettodes and some taxa of the cara group originated, and speciation expansion occurred in the cara group shortly thereafter during a short period in the initial diversification of carangimorphs. At meantime, none of the flatfishes underwent speciation expansion. Only in a later period of the middle Paleocene pleuronectoids did undergo speciation expansion (Fig. 2, node d).

From the initial origin of Psettodes to the modern era, a duration of over approximately 60 million years, no diversification has occurred within the lineage of Psettodes, with the Psettodes clade representing as a long, naked branch in phylogenies. The only genus Psettodes in family Psettodidae comprises Psettodes belcheri Bennett 1831, Psettodes bennettii Steindachner 1870 and Psettodes erumei (Bloch \& Schneider 1801). We constructed a phylogenetic tree based on $16 \mathrm{~S}$ rRNA sequences (Additional file 3: Figure S2), and the topology showed all three Psettodes species as being very closely related and a long and naked branch leading to the Psettodes clade. The long and naked branch is likely the result of long-branch attraction (LBA), which can lead to anomalous groupings of long lineages in a phylogeny. Siddall and Whiting (1999) indicated that if the phylogenetic relationships among taxa change when LBA taxa 
are systematically removed from the analysis one at a time, this is good evidence of LBA. Thus, we removed the LBA Psettodes taxa and re-constructed the phylogenetic tree (Additional file 4: Figure S3). The phylogenetic relationships changed markedly: Polydactylus plebeius and Polydactylus sextarius, which formerly clustered with flatfishes in Fig. 1, now clustered with the cara-group taxa. In addition, the cara-group clade showed a strong ability to attract the Psettodes clade because the time of speciation expansion for the cara group was very early and very close to the time of origin of the Psettodes lineage (Fig. 2, node b \& c), making the cara-group clade both "weighty" and closely related to the Psettodes clade. In this scenario, the pleuronectoid clade exhibits no advantage over the cara-group clade in the competition for attraction of the Psettodes clade in the phylogenetic analysis.

The above conclusions are supported by the timetree based on a Bayesian relaxed clock constructed by Campbell et al. [18] in which flatfishes were not monophyletic, and Psettodes was sister to some cara-group taxa; however, the origin of the Psettodes clade and the divergence between the cara-group lineage and the pleuronectoid lineage were very close in time, as evidenced by the short branch lengths, after the first divergence of the carangimorphs.

\section{Conclusions}

The monophyly of Pleuronectoidei is strongly supported by many large-scale fish phylogenetics studies, but whether the other suborder of flatfishes, Psettodoidei, is closely related to Pleuronectoidei has been difficult to determine. In this study, we examined why flatfish monophyly is difficult to ascertain.

In conclusion, the inconsistent phylogenetic results regarding the placement of Psettodes could be due to the origin of the Psettodes lineage occurring very close in time to the initial diversification of Carangimorphariae or to the initial diversification of pleuronectoids (the other suborder of flatfishes) occurring later than that of the cara group. In these scenarios, the cara-group clades would inevitably affect the clustering of Psettodes in phylogenetic analyses. The other important reason for the uncertain phylogenetic placement of the Psettodes clade has a long and naked branch, which is likely an artifact of LBA. With the ongoing advances in phylogenomics and high-throughput sequencing at the genome level, phylogenies will become more accurate, and the question of flatfish monophyly will eventually be answered.

\section{Additional files}

Additional file 1: Table S1. Primers used to amplify fragments of the Psettodes erumei, Samaris cristatus, Achirus lineatus, Trinectes maculatus and Cynoglossus nanhaiensis mitochondrial genomes (DOCX 18 kb)
Additional file 2: Figure S1. a Relationships of Carangimorphariae taxa inferred from the Bayesian analysis $\mathrm{v} 3.2$ of the 50 taxa of dataset $1_{\mathrm{N}} 2_{\mathrm{N}}$. Numbers above or below the branches indicate Bayesian posterior probabilities (shown as percentages). b Relationships of Carangimorphariae taxa inferred from the Bayesian analysis version 3.2 of 50 taxa of dataset $1_{N} 2_{N} 3_{R Y}$. Numbers above or below internal branches indicate Bayesian posterior probabilities (shown as percentages). c Relationships of Carangimorphariae taxa inferred from the Bayesian analysis version 3.2 of the 50 taxa of dataset $1_{N} 2_{N} R T$. Numbers above or below internal branches indicate Bayesian posterior probabilities (shown as percentages). $\mathbf{d}$ Relationships of Carangimorphariae taxa inferred from the Bayesian analysis version 3.2 of 50 taxa of dataset $1{ }_{N}{ }_{3} B_{R} R T$. Numbers above or below internal branches indicate Bayesian posterior probabilities (shown as percentages). e A maximum likelihood (ML) tree generated in RAxML version 8.0.0 under a GTR $+\lceil$ model of nucleotide evolution. The 50 taxa mitogenomes were partitioned by codon position (1 2 ). $\mathbf{f}$ A maximum likelihood (ML) tree generated in RAxML version 8.0.0 under a GTR $+\lceil$ model of nucleotide evolution. The 50 taxa mitogenomes were partitioned by codon position with the third codons recoded $\left(1_{N}{ }_{N} 3_{R Y}\right)$. g A maximum likelihood (ML) tree generated in RAxML version 8.0.0 under a GTR $+\Gamma$ model of nucleotide evolution. The 50 taxa mitogenomes were partitioned by codon position, rRNA, and tRNA (1 $\left.2_{N} R T\right)$. (DOCX $2386 \mathrm{~kb}$ )

Additional file 3: Figure S2. Maximum likelihood (ML) tree generated in RAXML version 8.0.0 under a GTR $+\Gamma$ model of nucleotide evolution. The sequences of the $16 \mathrm{~S}$ gene were used; the cara-group background is blue, the Pleuronectoidei background is green, and the Psettodes background is red. (EPS $7422 \mathrm{~kb}$ )

Additional file 4: Figure S3. Maximum likelihood (ML) tree generated in RAXML version 8.0.0 under a GTR $+\Gamma$ model of nucleotide evolution without Psettodes taxa. The sequences of the first and second codon positions of coding sequences, the third codon position mitochondrial sequences (as purines and pyrimidines), rRNA and tRNA $\left(1_{N}{ }^{2}{ }_{N}{ }_{R Y} R T\right)$ were used. (EPS $7323 \mathrm{~kb}$ )

\section{Abbreviations}

$1_{N} 2_{N}$ : Concatenated dataset of the first, second codon positions of twelve coding sequences (ND6 excluded due to compositional heterogeneity); $1_{\mathrm{N}} 2_{\mathrm{N}} 3_{\mathrm{RY}}$ : Concatenated dataset of the first, second and third (defined only as purines and pyrimidines codon) of twelve coding sequences (ND6 excluded due to compositional heterogeneity); $1_{\mathrm{N}} 2_{\mathrm{N}} 3_{\mathrm{RY}} \mathrm{RT}$ : Concatenated dataset of the first, second and third positions (defined only as purines and pyrimidines codon) of twelve coding sequences (ND6 excluded due to compositional heterogeneity), 2 rRNAs and 22 tRNAs; $1_{N} 2_{N} R T$ : Concatenated dataset of the first, second codon positions of twelve coding sequences (ND6 excluded due to compositional heterogeneity), 2 rRNAs and 22 tRNAs; BI: Bayesian inference; BP: Bootstrap support; LBA: Long-branch attraction; MCMC: Markov chain Monte Carlo; ML: Maximum likelihood; MRCA: Most recent common ancestor; mtDNA: Mitochondrial deoxyribonucleic acid; Mya: Million years ago; PCR: Polymerase chain reaction; PP: Posterior probability; rRNA: Ribosomal Ribonucleic Acid; tRNA: Transfer Ribonucleic Acid

\section{Acknowledgements}

The authors would like to express their gratitude to Bernard P.H. YAU for authorizing to use his exquisite hand-drawn pictures, to Z. M. Wang and H. R. Luo for collecting and sampling, and gratitude is also expressed to X. G. Miao, S. Y. Wang, and J. X. Dong for their efforts in amplification of mitochondrial genome.

\section{Funding}

This work was supported by the Natural Science Foundation of China (grant numbers 30870283, 31471979 and 41206134) and Foshan University Research Start-up Project of High-caliber Personnel (GG040986).

\section{Availability of data and materials}

The datasets generated and/or analysed during the current study are available on the GenBank repository, https://www.ncbi.nlm.nih.gov/genbank/. GenBank accession numbers are listed in Table 1. GenBank accession number for the mtDNA of Psettodes erumei, Samaris cristatus, Achirus lineatus, Trinectes maculatus and Cynoglossus nanhaiensis are NC_020032, NC_025903, NC_023768, NC 023769 and MH317761, which were specially sequenced for this study. 


\section{Authors' contributions}

$\mathrm{XYK}, \mathrm{HY}$ and WS conceived and designed the research; WS collected and analyzed the datasets; WS and XSC wrote the manuscript; LZS, LG and YCZ performed the experiments. All authors have read and approved the manuscript.

\section{Ethics approval and consent to participate}

This study was carried out in strict accordance with the recommendations and guidelines of the National Institutes of Health. All experimental protocols were approved by the Research Ethics Committee of Chinese Academy of Sciences. No specific permits were required because the specimens used in this study were dead before we obtained them.

\section{Competing interests}

The authors declare that they have no competing interests.

\section{Publisher's Note}

Springer Nature remains neutral with regard to jurisdictional claims in published maps and institutional affiliations.

\section{Author details}

'College of Life Science, Foshan University, Foshan 528231, Guangdong, China. ${ }^{2}$ CAS Key Laboratory of Tropical Marine Bio-resources and Ecology, South China Sea Institute of Oceanology, Chinese Academy of Sciences, 164 West Xingang Road, Guangzhou 510301, China. ${ }^{3}$ University of Chinese Academy of Sciences, Beijing 100049, China.

Received: 16 August 2017 Accepted: 14 May 2018

Published online: 25 May 2018

\section{References}

1. Nelson JS, Grande T, MVH W. Fishes of the world. Fifth ed; 2016

2. Schwarzhans W. A comparative morphological treatise of recent and fossil otoliths of the order Pleuronectiformes, vol. 2. Germany: Verlag F. Pfeil; 1999.

3. Chanet B. A cladistic reappraisal of the fossil flatfishes record consequences on the phylogeny of the Pleuronectiformes (Osteichthyes: Teleostei). Ann Sci Nat Zool. 1997;18(3):105-16.

4. Friedman M. The evolutionary origin of flatfish asymmetry. Nature. 2008;454(7201):209-12.

5. Friedman M. Osteology of Heteronectes chaneti (Acanthomorpha, Pleuronectiformes), an Eocene stem flatfish, with a discussion of flatfish sister-group relationships. J Vert Paleontol. 2012;32(4):735-56.

6. Chapleau F. Pleuronectiform relationships: a cladistic reassessment. Bull Mar Sci. 1993;52(1):516-40.

7. Kyle HM. The asymmetry, metamorphosis and origin of flat-fishes. Philos Trans R Soc. 1921;211:75-128.

8. Chabanaud P. Le problème de la phylogénèse des Heterosomata. Bull Inst Oceanogr. 1949;950:1-24.

9. Norman JR. A systematic monograph of the flatfishes (Heterosomata). London: Printed by order of the Trustees of the British Museum; 1934.

10. Hensley D, Ahlstrom E. Pleuronectiformes: relationships. In: Ontogeny and systematics of fishes. Edited by Moser H, Richards W, Cohen D, Fahay M, Kendell A, Richardson S. American Society of Ichthyologists and Herpetologists; 1984. p. 670-687.

11. Cooper JA, Chapleau F. Monophyly and intrarelationships of the family Pleuronectidae (Pleuronectiformes), with a revised classification. Fish Bull. 1998;96(4):686-726.

12. Wainwright $P C$, Smith WL, Price SA, Tang KL, Sparks JS, Ferry LA, Kuhn KL, Eytan Rl, Near TJ. The evolution of pharyngognathy: a phylogenetic and functional appraisal of the pharyngeal jaw key innovation in labroid fishes and beyond. Syst Biol. 2012;61(6):1001-27.

13. Kawahara R, Miya M, Mabuchi K, Lavoue S, Inoue JG, Satoh TP, Kawaguchi A, Nishida M. Interrelationships of the 11 gasterosteiform families (sticklebacks, pipefishes, and their relatives): a new perspective based on whole mitogenome sequences from 75 higher teleosts. Mol Phylogenet Evol. 2008; 46(1):224-36.

14. Dettaï $A$, Lecointre $G$. New insights into the organization and evolution of vertebrate IRBP genes and utility of IRBP gene sequences for the phylogenetic study of the Acanthomorpha (Actinopterygii: Teleostei). Mol Phylogenet Evol. 2008;48(1):258-69.
15. Dettai A, Lecointre G. Further support for the clades obtained by multiple molecular phylogenies in the acanthomorph bush. C R Biol. 2005;328(7): 674-89.

16. Miya M, Takeshima $H$, Endo $H$, Ishiguro NB, Inoue JG, Mukai T, Satoh TP, Yamaguchi M, Kawaguchi A, Mabuchi K, et al. Major patterns of higher teleostean phylogenies: a new perspective based on 100 complete mitochondrial DNA sequences. Mol Phylogenet Evol. 2003;26(1):121-38.

17. Chen WJ, Bonillo C, Lecointre G. Repeatability of clades as a criterion of reliability: a case study for molecular phylogeny of Acanthomorpha (Teleostei) with larger number of taxa. Mol Phylogenet Evol. 2003;26(2):262-88.

18. Campbell MA, Chen WJ, López JA. Are flatfishes (Pleuronectiformes) monophyletic? Mol Phylogenet Evol. 2013;69(3):664-73.

19. Betancur-R R, Li C, Munroe TA, Ballesteros JA, Orti G. Addressing gene tree discordance and non-stationarity to resolve a multi-locus phylogeny of the flatfishes (Teleostei: Pleuronectiformes). Syst Biol. 2013;62(5):763-85.

20. Betancur RR, Broughton RE, Wiley EO, Carpenter K, Lopez JA, Li C, Holcroft $\mathrm{NI}$, Arcila D, Sanciangco M, Cureton JC II, et al. The tree of life and a new classification of bony fishes. PLoS Curr. 2013;18:5.

21. Shi $W$, Kong $X Y$, Wang ZM, Jiang JX. Utility of tRNA genes from the complete mitochondrial genome of Psetta maxima for implying a possible sister-group relationship to the Pleuronectiformes. Zool Stud. 2011:50(5):665-81.

22. Little AG, Lougheed SC, Moyes CD. Evolutionary affinity of billfishes (Xiphiidae and Istiophoridae) and flatfishes (Plueronectiformes): independent and trans-subordinal origins of endothermy in teleost fishes. Mol Phylogenet Evol. 2010;56(3):897-904.

23. Li B, Dettaï A, Cruaud C, Couloux A, Desoutter-Meniger M, Lecointre G. RNF213, a new nuclear marker for acanthomorph phylogeny. Mol Phylogenet Evol. 2009;50(2):345-63.

24. Smith WL, Wheeler WC. Venom evolution widespread in fishes: a phylogenetic road map for the bioprospecting of piscine venoms. J Hered. 2006;97(3):206-17

25. Smith WL, Craig MT. Casting the percomorph net widely: the importance of broad taxonomic sampling in the search for the placement of serranid and percid fishes. Copeia. 2007:1:35-55

26. Campbell MA, Lopez JA, Satoh TP, Chen WJ, Miya M. Mitochondrial genomic investigation of flatfish monophyly. Gene. 2014;551(2):176-82.

27. Betancur-R R, Orti G. Molecular evidence for the monophyly of flatfishes (Carangimorpharia: Pleuronectiformes). Mol Phylogenet Evol. 2014;73:18-22.

28. Campbell MA, Chen WJ, López JA. Molecular data do not provide unambiguous support for the monophyly of flatfishes (Pleuronectiformes): a reply to Betancur-R. And Ortí. Mol Phylogenet Evol. 2014;75:149-53.

29. Near TJ, Eytan RI, Dornburg A, Kuhn KL, Moore JA, Davis MP, Wainwright PC, Friedman M, Smith WL. Resolution of ray-finned fish phylogeny and timing of diversification. P Natl Acad Sci USA. 2012;109(34):13698-703.

30. Harrington RC, Faircloth BC, Eytan RI, Smith WL, Near TJ, Alfaro ME, Friedman M. Phylogenomic analysis of carangimorph fishes reveals flatfish asymmetry arose in a blink of the evolutionary eye. BMC Evol Biol. 2016;16(1):224.

31. Hall TA. BioEdit: a user-friendly biological sequence alignment editor and analysis program for windows 95/98/NT. Nucleic Acids Symp Ser. 1999;41: 95-8

32. Lowe TM, Eddy SR. tRNAscan-SE: a program for improved detection of transfer RNA genes in genomic sequence. Nucleic Acids Res. 1997;25(5): 955-64

33. Hillis DM, Huelsenbeck JP. Signal, noise, and reliability in molecular phylogenetic analyses. J Hered. 1992:83(3):189-95.

34. Thompson JD, Gibson TJ, Plewniak F, Jeanmougin F, Higgins DG. The CLUSTAL_ $X$ windows interface: flexible strategies for multiple sequence alignment aided by quality analysis tools. Nucleic Acids Res. 1997;25(24):4876-82.

35. Talavera G, Castresana J. Improvement of phylogenies after removing divergent and ambiguously aligned blocks from protein sequence alignments. Syst Biol. 2007;56(4):564-77.

36. Xia X, Xie Z. DAMBE: software package for data analysis in molecular biology and evolution. J Hered. 2001;92(4):371-3.

37. Ronquist F, Huelsenbeck JP. MrBayes 3: Bayesian phylogenetic inference under mixed models. Bioinformatics. 2003;19(12):1572-4.

38. Leavitt JR, Hiatt KD, Whiting MF, Song H. Searching for the optimal data partitioning strategy in mitochondrial phylogenomics: a phylogeny of Acridoidea (Insecta: Orthoptera: Caelifera) as a case study. Mol Phylogenet Evol. 2013;67(2):494-508

39. Nylander JA, Ronquist F, Huelsenbeck JP, Nieves-Aldrey UL. Bayesian phylogenetic analysis of combined data. Syst Biol. 2004;53(1):47-67. 
40. Stamatakis A, Ludwig T, Meier H. RAxML-III: a fast program for maximum likelihood-based inference of large phylogenetic trees. Bioinformatics. 2005;21(4):456-63.

41. Thorne JL, Kishino H. Divergence time and evolutionary rate estimation with multilocus data. Syst Biol. 2002;51(5):689-702.

42. Drummond AJ, Ho SYW, Phillips MJ, Rambaut A. Relaxed phylogenetics and dating with confidence. PLoS Biol. 2006;4(5):699-710.

Ready to submit your research? Choose BMC and benefit from:

- fast, convenient online submission

- thorough peer review by experienced researchers in your field

- rapid publication on acceptance

- support for research data, including large and complex data types

- gold Open Access which fosters wider collaboration and increased citations

- maximum visibility for your research: over $100 \mathrm{M}$ website views per year 